УДК 355.233:811(477)

Вікторія Крикун, кандидат педагогічних наук, Національний університет оборони України імені Івана Черняховського, м. Київ

ORCID ID: 0000-0001-7409-3383

DOI: $10.33099 / 2617-1775 / 2021-01 / 154-164$

\title{
РЕТРОСПЕКТИВНИЙ АНАЛІЗ РОЗВИТКУ ІНТЕЛЕКТУАЛЬНИХ АДАПТИВНИХ СИСТЕМ НАВЧАННЯ
}

У статті проаналізованоособливості розвитку інтелектуальних адаптивних систем у наукових прачях украӥнських $i$ зарубіжних учених у ретроспективному вимірі. Авторка дослідила передумови виникненнятаких систем та їх структурні компоненти з метою створення інтелектуальної адаптивної системи іншомовної підготовки офіцерів Збройних Сил Украӥни в умовах неформальної освіти.Визначено, щяо сьогодні науковиі зосереджують свої зусилля на підвищенні адаптивності досліджуваних систем завдяки використанню комплексних моделей студента й навчання з елементами штучного інтелекту через створення адаптивних хмаро орієнтованих систем навчального призначення.Обтрунтовано різні можливості інтелектуальних адаптивних систем та їх особливості у контексті адаптації до змін студента, надання зворотного зв'язку викладачеві (студентові) $\check{u}$ інтелектуальної підтримки, трунтуючись на потребах суб'єкта навчання.

Ключові слова: програмоване навчання, адаптивний алгоритм, штучний інтелект, комп'ютерне адаптивне тестування, цицррова трансформація, неперервна освіта.

Поставлення проблеми у загальному вигляді. У контексті стрімких соціально-економічних та технологічних зміннабуває особливого значення цифровізація освітнього процесу. Ситуація в Україні, яка склалася у зв'язку 3 пандемієюCOVID-19 пришвидшила впровадженняінноваційних технологійв освітній процес. Сучасна освіта стоїть на порозі цифрової трансформації, яка дає поштовх глобальним змінам, оскільки передбачає не тільки автоматизацію та цифровізацію окремих операцій та процедур, а й зміну парадигми функціонування освітніх інституцій[6].

У сучасному глобальному світі масив інформації та темпи іiі поширення суттєво збільшилися, а сфери діяльності викладачів розширилися. Тому в еру цифрових технологій розробляються та активно впроваджуються у сферу освіти інноваційні технології, зокрема технології штучного інтелекту (ШІ), які $\epsilon$ рушійною силою для масштабних змін, а саме: дедалі більший спектр функцій, які раніше покладалися лише на викладача, як-от збір та аналіз інформації щодо успішності навчання студентів, здійснення комунікації та надання своєчасного зворотного зв’язку й оцінювання, сьогодні автоматизуються за активного впровадження інтелектуальних адаптивних систем навчання (IAC).

Один iз найбільш популярних запитів сьогодення - забезпечення індивідуального підходу до навчання, а також створення персоніфікованого навчального середовища. Така вимога сучасного суспільства спонукає до дослідження історії створення інтелектуальних та адаптивних систем навчання 
3 метою обгрунтування структурних компонентів IAC іншомовної підготовки в Збройних Силах (ЗС) України.

Мета статті -проаналізувати процес становлення інтелектуальних адаптивних систем у наукових працях українських і зарубіжних дослідників у ретроспективному вимірі та з'ясувати особливості їх використання в освітньому процесі.

Для досягнення мети ми визначили такі завдання: 1) дослідити передумови створення інтелектуальних та адаптивних систем навчання; 2) вивчити структурні компоненти досліджуваних систем 3 метою створення інтелектуальної адаптивної системи іншомовної підготовки офіцерів ЗС України в умовах неформальної освіти.

Виклад основного матеріалу. Історія застосування ШІ в освіті сягає 20-х років XX століття, коли відомий психолог СідніЛ. Прессі, професор Університету штату Огайо представив на засіданні Американської психологічної асоціації та Американської асоціації розвитку науки прототип автоматизованоїінтелектуальної машини для тестування («Automatic Intelligence Testing Machine»), яка згодом отримала назву «Автоматизований вчитель» («Automatic Teacher») [20]. Винахід психолога генерував тест, який складався із тридцяти завдань множинного вибору різного рівня складності. Завдання мали ключі - правильні відповіді, та три дистрактори - неправильні відповіді; вони пропонувалися користувачеві одне за одним, рівень складності змінювався, фіксувалися тільки правильні відповіді [17].

Перша версія «Автоматизованого вчителя» була розкритикована психологами-біхевіористами, але Сідні Л. Прессі не зупинявся на досягнутому, і наступна версія «Автоматизованого вчителя» давала змогу вже виконувати функцію діагностики та самодіагностики студента, оскільки під час тестування рівень складності завдань підвищувався після надання двох правильних відповідей, що актуалізувало психологічні закони, запропоновані Едвардом Лі Торндайком, - «ефект» («lawofeffect») та «вправа» («lawofexercise») - та робило процес навчання індивідуальним для кожного студента $[17 ; 23]$.

Основні преваги «Автоматизованого вчителя» Сідні Л. Прессі вбачав у негайному зворотному зв'язку, а інші - у самонавчанні через процес тестування, оскільки апарат показував правильні та неправильні відповіді. Учений Сідні Л. Прессі винайшов апарат, який надавав індивідуальний зворотний зв'язок, тому автоматизований стандартизований тест, на думку науковця, слугував ще й інструментом навчання [17; 20].

Отже, на автоматизовані машини для навчання та тестування покладалися такі завдання: представлення тестових завдань студенту; фіксація відповідей на тестові завдання; аналіз відповідей та надання зворотного зв'язку; вибір складності наступного завдання (якщо передбачається); оцінювання відповідно до обраної шкали. Такий підхід зменшував вплив суб'єктивних чинників на результати тестування та навчання - ставлення викладача (або тестолога) до суб'єкта навчання, зменшував неточності в обрахунку балів, зменшував ризик відкладеного зворотного зв’язку. 
Як ми бачимо, метою автоматизованої навчальної машини Сідні Л. Прессі вбачав створення умов для впровадження принципів індивідуального навчання в контексті масової освіти. Науковець вважав, що його винахід дасть змогу звільнити викладача від механічних рутинних функцій (паперової роботи, перевірки тестових завдань тощо), для того, щоби зосередитись на індивідуальній співпраці 3 кожним студентом та підвищенні рівня своєї професійної компетентності.

Необхідність автоматизації другорядних функцій викладача $є$ нагальним завданням і в XXI столітті, що підтверджується результатами наукового дослідження "Global Teacherand Teacher Survey», проведене компанією McKinsey разом iз Microsoft у 2017 році, в якому взяли участь понад 2000 учасників - викладачів із Канади, Сінгапуру, Великої Британії та Сполучених Штатів Америки. Результати дослідження показали, що викладачі, які мають навантаження в середньому 50 годин на тиждень приділяють тільки 49 \% свого часу безпосередній взаємодії зі студентами, а решту - підготовці до занять (10,5 годин), оцінюванню та наданню зворотного зв'язку (6,5 годин), професійному розвитку (3 години) і виконанню адміністративних завдань (5 годин) [12]. За даними Forbes, очікується, що до 2024 року Ш буде наділено понад $47 \%$ інструментів управління навчанням. Рон Шмельцер, експерт компанії Cognilytica $з$ питань ШІ, вважає, що інтелектуальні помічники допоможуть освітянам не тільки звільнитися від рутинних справ, а й дадуть змогу втілити концепцію адаптивного навчання для забезпечення потреб кожного студента [22].

Аналіз зарубіжних наукових розвідок показав, що здебільшого учені вважають, що перша навчальна машина була створена Сідні Л. Прессі, але $\epsilon$ дослідники, які віддають першість ідеї програмованого навчання поляку С. Трембицькому, який у 1920 році запатентував пристрій сприяння навчанню без сторонньої допомоги [4; 9].

У 50-60 роки XX століття почали активно розвиватися алгоритми програмованого навчання, основним завданням яких стала побудова «розумних» способів надання інформації. Такі програми, за задумом дослідників, мали забезпечити адекватний контроль знань студентів, а також підвищити ефективність поетапного засвоєння навчального матеріалу. Відомий психолог-біхевіорист Б. Скіннер, розвиваючи ідею Сідні Л. Прессі, запропонував навчальну машину, яка передбачала надання розгорнутої відповіді на відміну від апарату Сідні Л. Прессі. Система навчання отримала назву лінійного програмування. Вона виконувала роль персонального тьютора, який пропонує навчальний матеріал порціями відповідно до рівня знань студента; демонструє наступне завдання за умови, якщо правильно виконане попереднє та надає постійний зворотний зв'язок, щоби корегувати його поведінку в навчанні [21]. Тестові запитання та порядок пред'явлення, а також контент програми були заздалегідь запрограмовані й не адаптувалися до потреб кожного студента. Це дає змогу зробити висновок, що винахід Б. Скіннера поки не можна вважати IAC навчання або тестування. Інтелектуальною системою вважається самокерована кібернетична система, яка має певну суму знань про 
світ і здатна на основі безпосереднього сприйняття й подальшого аналізу поточної ситуації планувати дії, спрямовані на досягнення певної мети, а також поповнювати свої знання [3]. Своєю чергою, адаптивні системи фокусуються на адаптації контенту для кожного студента і групи загалом завдяки накопиченню інформації в обліковому профілі в індивідуальній або груповій моделі студентів [11].

Розгалужений алгоритм програмованого навчання був створений Н. Краудером у 1960 році для підготовки інженерів військово-повітряних сил США. Запропонована програма була поверненням до тестових завдань множинного вибору. Принцип роботи алгоритму полягав у тому, що спочатку програма представляла тестове завдання, а потім, відповідно до відповіді студента, пропонувала йому наступне завдання за умови, що він дав правильну відповідь, а в іншому випадку - надавала йому зворотній зв'язок, або ж відкривала додаткові сторінки 3 навчальним матеріалом. Отже, набір і зміст таких «сторінок» у кожного студента формувався відповідно до його навчальних потреб та індивідуальних особливостей [14].

Система адаптивного програмованого навчання, запатентована Г. Паском та Р. Вудом «Self-Adaptive Keyboard Instructor» (SAKI) у 1956 році, будується на основі гнучкого пристосування алгоритму навчання до індивідуальних можливостей студентів. Критерієм для оцінювання можливостей студентів $\mathrm{i}$ вибору складності завдань слугують їхні неправильні відповіді, які вказують на те, як студент справляється із завданням: якщо відсоток помилок зростає вище запрограмованого рівня, це вказує на те, що складність завдань для цього студента є занадто високою. У такому разі він має можливість відмовитися від виконання завдання після низки невдалих спроб. Орієнтуючись на такі дії студента, програма автоматично знижує рівень складності завдань. I навпаки якщо студент майже не допускає помилок, такі дії сигналізують про те, що запропоновані завдання є занадто легкими для нього, й алгоритм пропонує завдання вищої складності, для того щоб у студента не знизилася мотивація [16].

Комп'ютерне навчання (Computer-Based Training) виникло в 1960 році в США, коли була розроблена система PLATO (від англ. Programmed Logic For Automated Teaching Operations), Coursewar (розробка IBM), Fabritek (розробка Альбертського університету), ТICСЕТ (від англ. Time-Shared Interactive Computer Controlled Information Television, розробка корпорації MITRE) [1; 15].

У 1970 році Ж. Карбонеллу перше запропонував наділити програмоване навчання ШI. Він розробив систему SCHOLAR, яка могла вести діалог та надавати різні відповіді на твердження студентів за допомогою семантичних зв'язків. SCHOLAR вважається першою інтелектуальною навчальною системою (IHC) («Intelligent Computer Assisted Learning»). SCHOLAR давала змогу здійснювати покрокове навчання, створювала індивідуальний шлях опанування навчального матеріалу [13].

Е. Венгер визначив архітектуру IHC, яка й сьогодні є актуальною [25]:

а) модель предметної області (експертна модель) містить концепції, поняття, правила, знання, які має опанувати студент; 
б) модель студента - ключова модель, яка виконує п’ять функцій: 1) збирає імпліцитні та експліцитні дані щодо студента та від нього; 2) використовує зібрані дані для формування профілю студента щодо його знань та успіхів; 3) діагностує - визначає прогалини в знаннях студента; 4) прогностичну - допомагає визначити ймовірну реакцію студента на педагогічні впливи; 5) оцінювальну - допомагає оцінити знання студента, містить інформацію щодо кожного студента, яку використовує для побудови індивідуального шляху навчання;

в) модель викладання (педагогічна модель) - отримує вхідні дані від моделі предметної області та моделі студента для того, щоби обрати стратегію навчання та здійснити необхідні дії.

У межах напряму адаптивного програмованого навчання 1974 року 3'явилося адаптивне тестування, яке відповідало за обробку величезного обсягу інформації під час опанування навчальної програми [18]. Сьогодні активно розвивається комп'ютерне адаптивне тестування (КАТ), різновид тестування, під час якого порядок представлення запитань (або складність) залежить від відповідей на попередні запитання того, хто тестується. Існує три основні види КАТ: пірамідальне - тестування починається із пред'явлення завдань середнього рівня складності, а у ході тестування пропонуються завдання вищого або нижчого рівня складності; flexilevel-контроль - студент має змогу самостійно обрати рівень складності завдань; стратифіковано-адаптивний передбачає створення банку тестових завдань, розділених за рівнями складності. За умови надання правильної відповіді наступне завдання обирається з банку вищого рівня, а якщо студент робить помилку - 3 нижчого рівня [7].

Дослідники КАТ виокремлюють такі його переваги: скорочення часу та ресурсів на проходження тестування; забезпечення індивідуального підходу до кожного студента на основі їхніх індивідуальних здібностей і рівня знань; підвищення мотивації, оскільки студенту не пропонуються занадто легкі, або занадто складні завдання; завдяки автоматизації спрощення процедури перевірки бланків відповідей надання миттєвого зворотного зв'язку; забезпечення конфіденційності завдяки наданню індивідуального набору тестових завдань [19].

Створення та постійний розвиток мережі Інтернет дав поштовх у 19951996 роках до створення адаптивних і інтелектуальних освітніх інтернет-систем ((AIOIC), від. англ. Adaptive and Intelligent Web-Based Educational Systems), які сьогодні набувають ще більше рис адаптивності завдяки побудові моделі цілей, вподобань та знань для кожного окремого студента, використовуючи цю модель упродовж взаємодії зі студентом із метою пристосування до його потреб [10]. Вони також намагаються бути інтелектуальними, об'єднуючи i виконуючи певні функції викладача. Джерелами AIOIC науковці визначають [2]:

адаптивне гіпермедіа (адаптивна підтримка навігації, адаптивне подання); адаптивна фільтрація інформації (фільтрація на основі вмісту; сумісна фільтрація). Адаптивні гіпермедіа-системи - це усі гіпермедіа-системи, які 
зберігають особливості користувача в його моделі й застосовують іiі для адаптації до користувача різних візуальних аспектів системи. Система має задовольняти трьом критеріям: має бути гіпертекстовою або гіпермедійною, мати модель користувача і адаптувати свій гіпермедіа-простір, використовуючи цю модель;

інтелектуальний моніторинг класу: передбачає застосування ШІ, який має на меті підтримку викладача та покладається на такі технології ШІ, як інтелектуальний аналіз даних (Data Mining) і машинне навчання;

інтелектуальне колективне навчання: адаптивне формування груп i рівноправна (партнерська) допомога; адаптивна підтримка співпраці (тренери та наставники); віртуальні студенти;

інтелектуальне навчання: викладання, програмування (планування) курсу навчання; інтелектуальний аналіз рішень; підтримка прийняття рішень тощо.

У XXI столітті науковці зосереджують свої зусилля на підвищенні адаптивності IHC завдяки використанню комплексних моделей студента й навчання з елементами ШІ через створення адаптивних хмаро орієнтованих систем навчального призначення. «Хмара» (Cloud Computing) - це великий масив легкодоступних віртуальних ресурсів (апаратних, програмних платформ та послуг). Ці ресурси можуть динамічно змінюватись, щоби пристосуватися до змін навантаження (масштабування), що зумовлює оптимальне їхнє використання [24]. Хмаро орієнтовані системи наділені характеристиками, якот: 1) наявністю віртуалізованої або гібридної інформаційно-комунікаційної інфраструктури; 2) персоналізацією сервісів; 3) відкритістю щодо модифікації та удосконалення; 4) доступністю (використання відкритого доступу, відкритих даних); 5) гнучкістю алгоритмів оцінювання складності матеріалу, знань студента, готовності до навчання; 6) наданням індивідуалізованої допомоги у процесі навчання; 7) можливістю автоматичного налаштування за низкою параметрів у режимі реального часу; 8) системністю будови і функцій [8].

Отже, ретроспективний аналіз розвитку інтелектуальних адаптивних систем спонукає нас до переосмислення ролі кожного учасника педагогічної взаємодії викладача-фахівця із машинним компонентом такої системи.

Науково-технічний прогрес суспільства завдяки можливостям сучасних інформаційно-комунікаційних технологій та ШІ робить машинний компонент навчальної системи активним партнером викладача. Окрім функції автоматичної механічної дії, збору інформації, iї оброблення та ухвалення рішення, технології IAC виконують ще й комунікативну функцію.

IAC не тільки виконує завдання для суб'єктів навчання, а й змінює їхню сутність. Вона (система) має можливість правильно адаптуватися до змін студента, тобто надає не тільки зворотний зв'язок викладачеві та студентові, а й інтелектуальну допомогу, грунтуючись на потребах суб'єкта навчання.

\section{ВИСНОВКИ}

Теоретичний аналіз порушеного питання показав, що основними завданнями застосування IAC в освіті, 3 одного боку, $є$ персоніфікація навчання, а $з$ іншого - звільнення викладача від рутинних адміністративних 
завдань задля творчої взаємодії із суб'єктами навчання. 3 огляду на зазначене, можна зробити висновки, які, на нашу думку, потребують подальших досліджень та дискусій:

1) зміна ролі викладача. Інновації в освіті, які фокусуються на автоматизації низки функцій викладача, пліч-о-пліч йдуть із потребою розвитку м'яких навичок (SoftSkills) суб' єктів навчання, які непритаманні IAC, як-от 1) креативність; 2) критичне мислення; 3) емоційний інтелект; 4) навички міжособистісної комунікації; 5) активне навчання та самовдосконалення; 6) здатність ухвалювати рішення; 7) лідерські якості; 8) міжкультурна компетентність тощо.

Звідси випливає, що сучасний педагог завдяки IAC має зосередити «звільнений час» на особистісному розвитку студентів, для того щоби в майбутньому вони успішно взаємодіяли в конкурентних умовах та в середовищі активного використання ШІ. Виконання зазначених завдань можливе за умови, якщо викладач стане фасилітатором, який постійно доповнює контент навчання, аналізує зворотний зв'язок від IAC, щоби ефективно співпрацювати в класі та максимально ефективно досягти визначеної мети навчання.

2) IAC як інструмент діагностики та прогнозування. IAC в освіті можуть слугувати інструментом діагностики прогалин у знаннях для викладачів, що допоможе спрогнозувати труднощі, які можуть виникнути в навчанні. Такий підхід забезпечує персоніфікований контент. Необхідно зауважити, що на викладача покладається вся відповідальність за результати навчання, оскільки IAC не можуть виступати самостійним інструментом навчання. Вони $\epsilon$ ефективними під час аналізу та інтерпретації даних, під час надання своєчасного зворотного зв'язку. Саме від викладача залежить, які функції автоматизувати, а які залишити недоторканими.

3) Готовність викладачів до активного застосування IAC. Іншим аспектом впровадження ШІ в освіту є готовність викладачів до активного застосування IAC, адже саме від викладачів залежить успішність використання технологій ШІ. Їм необхідно опановувати нові компетентності, зокрема цифрову, що $\epsilon$ інтегральною характеристикою особистості, яка динамічно поєднує знання, уміння, навички, ставлення щодо використання цифрових технологій для спілкування, власного розвитку, роботи, участі в суспільному житті відповідно до сфери компетенцій, належним чином (безпечно, творчо, критично, відповідально, етично) на рівні В1 та В2 [5, с. 52]. Високий рівень цифрової компетентності викладачів допоможе створювати максимально ефективні алгоритми, які будуть генерувати правильні та точні результати й презентувати актуальний навчальний матеріал.

4) Покрокове навчання.Аналіз наукових праць і досліджень показав, що більш ефективним $є$ покрокове навчання з використанням IAC. Такий підхід $\epsilon$ доречним, оскільки після кожного етапу алгоритм має проводити контроль, тестування або опитування для того, щоби продовжувати слідувати обраній стратегії або ж скорегувати іiі. Звідси випливає, що ми маємо справу 3 принципами мікронавчання (Microlearning), яке на сьогодні $\epsilon$ трендом. 
Вважаємо, що в контексті IAC треба скористатися його перевагами, щоби збільшити кількість нагод для IАC пристосуватися до потреб студента.

5) Забезпечення зворотного зв'язку. Сучасний викладач має постійно підвищувати свою діагностичну компетентність, оскільки в поєднанні 3 цифровою вона $є$ запорукою успіху IAC, яка постійно надає зворотний зв'язок чим повнішою $\epsilon$ інформація, - тим краще викладач розуміє траєкторію навчання студента.

Перспективами подальших досліджень вбачаємо дослідження сучасного стану впровадження інтелектуальних адаптивних систем у Збройних Силах України. Сьогодні активно розробляється методика комп'ютерного адаптивного мовного тестування, що сприяє автоматизації та інтелектуалізації процесу мовного тестування відповідно до вимог HATO STANAG 6001, а також в майбутньому слугуватиме діагностичним інструментом визначення мовного профілю офіцера, його здібностей та індивідуальних особливостей щодо опанування іноземних мов.

\section{ЛІТЕРАТУРА}

1. Воронкін, О. С. (2016). Тенденції розвитку інформаційно-комунікаційних технологій навчання студентів вищих навчальних закладів України (друга половина XX - початок XXI століття). Взято 3 http://luguniv.edu.ua/wp-content/uploads/2016/06/voronkin_dis.pdf

2. Гагарін, О. О., Титенко С. В. (2007). Дослідження і аналіз методів та моделей інтелектуальних систем безперервного навчання.Наукові вісті НТУУ «КПI», 6(56), 37-48.

3. Глибовець, М. М., Олецький О.В. (2002). Штучний інтелект.Київ: «КМ Академія», 27.

4. Коломієць, О. Б., Бондаренко Г. С.\&Головата О. О (2020).Кібернетичні засади програмованого навчання (за матеріалами публікацій у польській і радянській педагогічній періодиці 1960-х рр.). Наукові записки. Серія: Педагогічні науки, 188. Кропивницький : РВВ ЦДПУ ім. В. Винниченка, 99-105.

5. Опис рамки цифрової компетентності для громадян України (2021). Взято 3 https://thedigital.gov.ua/storage/uploads/files/news_post/2021/3/mintsifra-oprilyudnyue-ramkutsifrovoi-kompetentnosti-dlya-gromadyan/\%D0\%9E\%D0\%A0\%20\%D0\%A6\%D0\%9A.pdf

6. Осьодло, В. І.,Рибчук, О. О., Ворона Т. М. (2020). Наукові підходи до управління освітнім процесом у ВВНЗ. Військоваосвіта: зб. науковихпраць НУОУ, 2(42), 232 -242.DOI: https://doi.org/10.33099/2617-1775.2020.02.232.242

7. Федорук, П. І. (2008). Адаптивні тести: загальні положення. Математичні машини $i$ системи, 1, 115-127.

8. Шишкіна, М. П. (2015).Формування і розвиток хмаро орієнтованого освітньонаукового середовища вищого навчального закладу. Київ : УкрIНTЕI, 256.

9. Berezowski, E. S. (1966). Trębicki - prekursornauczaniaprogramowanego.NowaSzkoła, 53.

10. Brusilovsky, P. (1996).Methods and techniques of adaptive hypermedia.User Modeling and User-Adapted Interaction, 6(2-3), 87- 129.

11. Brusilovsky, P., Peylo, Ch. (2003).«Adaptive and Intelligent Web-based Educational Systems».International Journal of Artificial Intelligence in Education, 13, 156-169.

12. Bryant, J. Heitz, C., Sanghvi, S. \& Wagle, D. (2020). How artificial intelligence will impact K-12 teachers. McKinsey \& Company. Взято 3 https://www.mckinsey.com/ /media/McKinsey/Industries/Public\%20and\%20Social\%20Sector/Our \%20Insights/How\%20artificial\%20intelligence\%20will\%20impact\%20K\%2012\%20teachers/Howartificial-intelligence-will-impact-K-12-teachers.pdf. 
13. Carbonell, J. R.(1970)«AI in CAI: An Artificial-intelligence Approach to Computer Assisted Instruction». IEEE Transactions on Man-Machine Systems, 11(4), 190-202. doi:10.1109/ TMMS.1970.299942

14. Crowder, N. C. (1960). «Automatic Tutoring by Means of Intrinsic Programming in Teaching Machines and Programmed Learning», 116. Lumsdaine, A. A.\& Glaser, R. (eds.) American Psychological Association, 286-298.

15. Hou, M., Fidopiastis, C. (2017). A generic framework of intelligent adaptive learning systems: from learning effectiveness to training transfer. Theoretical Issues in Ergonomics Science, 18:2, 167-183. DOI: 10.1080/1463922X.2016.1166405

16. Pask, G. (1982). «SAKI: Twenty-five years of adaptive training into the microprocessor era».International Journal of Man-Machine Studies,17(1), 69-74. https://doi.org/10.1016/S00207373(82)80009-6

17. Petrina, S. (2004). Sidney Pressey and the Automation of Education, 1924-1934. Technology and Culture,45,305-330. DOI 10.1353/tech.2004.0085

18. Reckase, M. D. (1974). An interactive computer program for tailored testing based on the one-parameter logistic model. Behavior Research Methods and Instrumentation, 6(2), 208-212.

19. Rezaie, M., Golshan, M. (2015).Computer Adaptive Test (CAT): Advantages and Limitations.International Journal of Educational Investigations, 2(5), 128-137.

20. Pressey, S., «A Simple Self-Recording Double-Action Multiple Choice Apparatus».Psychological Bulletin, 22(1925), 111.

21. Skinner, B. F. (1958). “Teaching machines.” Science 128 (3330): 969-77.

22. Schmelzer, R.AI Applications In Education. Retrieved from https://www.forbes.com/sites/cognitiveworld/2019/07/12/ai-applications-in-education/

23.Thorndike, E. L. (1898). Animal intelligence: Anex perimental study of the associative proces sesinanimals. ThePsychologicalReview: MonographSupplements, 2(4), i109. https://doi.org/10.1037/h0092987

24. Vaquero, Luis, Rodero-Merino, Luis, Caceres, Juan \& Lindner, Maik. (2009). A Break in the Clouds: Towards a Cloud Definition. Computer Communication Review, 39, 50-55. DOI:10.1145/1496091.1496100

25.Wenger, E. (1987). Artificial Intelligence and Tutoring Systems. Los Altos, CA: Morgan Kaufmann Publisher.

\section{REFERENCES}

1.Voronkin, O. S. (2016). Tendentsiirozvytku informatsiino-komunikatsiinykh tekhnolohiinavchanniastudentivvyshchykhnavchalnykhzakladivUkrainy (druhapolovyna XX pochatok XXI stolittia). Retrieved from http://luguniv.edu.ua/wpcontent/uploads/2016/06/voronkin_dis.pdf

2. Haharin, O. O., Tytenko S. V. (2007). Doslidzhennia i analizmetodivtamodeleiintelektualnykhsystembezperervnohonavchannia. Naukovivisti NTUU «KPI», 6(56), 37-48.

3. Hlybovets, M. M., Oletskyi O.V. (2002). Shtuchnyiintelekt.Kyiv: «KM Akademiia», 27.

4. Kolomiiets, O. B., Bondarenko H. S. \&Holovata O. O (2020). Kibernetychnizasadyprohramovanohonavchannia (zamaterialamypublikatsii u polskii i radianskiipedahohichniiperiodytsi 1960-kh rr.).Naukovizapysky. Seriia: Pedahohichninauky, 188.Kropyvnytskyi : RVV TsDPUim. V. Vynnychenka, 99-105.

5. OpysramkytsyfrovoikompetentnostidliahromadianUkrainy (2021). Vziato z https://thedigital.gov.ua/storage/uploads/files/news_post/2021/3/mintsifra-oprilyudnyue-ramkutsifrovoi-kompetentnosti-dlya-gromadyan/\%D0\%9E\%D0\%A0\%20\%D0\%A6\%D0\%9A.pdf

6. Osodlo, V. I., Rybchuk, O. O., Vorona T. M. (2020). Naukovipidkhody do upravlinniaosvitnimprotsesom u VVNZ. Viiskovaosvita: Zb. naukovykhprats NUOU, 2(42), 232 242.DOI: https://doi.org/10.33099/2617-1775.2020.02.232.242

7. Fedoruk, P. I. (2008). Adaptyvnitesty: zahalnipolozhennia.Matematychnimashyny $i$ systemy, 1, 115-127. 
8. Shyshkina, M. P. (2015). Formuvannia i rozvytokkhmarooriientovanoho osvitnonaukovoho seredovyshchavyshchohonavchalnohozakladu.Kyiv : UkrINTEI, 256.

9. Berezowski, E. S. (1966). Trębicki - prekursornauczaniaprogramowanego.NowaSzkoła, 53.

10. Brusilovsky, P. (1996).Methods and techniques of adaptive hypermedia.User Modeling and User-Adapted Interaction, 6(2-3), 87- 129.

11. Brusilovsky, P., Peylo, Ch. (2003). «Adaptive and Intelligent Web-based Educational Systems».International Journal of Artificial Intelligence in Education, 13, 156-169.

12. Bryant, J. Heitz, C., Sanghvi, S. \& Wagle, D. (2020). How artificial intelligence will impact $\quad \mathrm{K}-12$ teachers. McKinsey \& Company. Взято 3 https://www.mckinsey.com/ /media/McKinsey/Industries/Public\%20and\%20Social\%20Sector/Our $\%$ 20Insights/How\%20artificial\%20intelligence\%20will\%20impact\%20K\%2012\%20teachers/Howartificial-intelligence-will-impact-K-12-teachers.pdf

13. Carbonell, J. R.(1970) «AI in CAI: An Artificial-intelligence Approach to Computer Assisted Instruction».IEEE Transactions on Man-Machine Systems, 11(4), 190-202. doi:10.1109/ TMMS.1970.299942

14. Crowder, N. C. (1960). «Automatic Tutoring by Means of Intrinsic Programming in Teaching Machines and Programmed Learning», 116. Lumsdaine, A. A.\& Glaser, R. (eds.) American Psychological Association, 286-298.

15. Hou, M., Fidopiastis, C. (2017). A generic framework of intelligent adaptive learning systems: from learning effectiveness to training transfer. Theoretical Issues in Ergonomics Science, 18:2, 167-183. DOI: 10.1080/1463922X.2016.1166405

16. Pask, G. (1982). «SAKI: Twenty-five years of adaptive training into the microprocessor era».International Journal of Man-Machine Studies, 17(1), 69-74. https://doi.org/10.1016/S00207373(82)80009-6

17. Petrina, S. (2004). Sidney Pressey and the Automation of Education, 1924-1934. Technology and Culture,45, 305-330. DOI 10.1353/tech.2004.0085

18. Reckase, M. D. (1974). An interactive computer program for tailored testing based on the one-parameter logistic model. Behavior Research Methods and Instrumentation, 6(2), 208-212.

19. Rezaie, M., Golshan, M. (2015).Computer Adaptive Test (CAT): Advantages and Limitations.International Journal of Educational Investigations, 2(5), 128-137.

20. Pressey, S., «A Simple Self-Recording Double-Action Multiple Choice Apparatus».Psychological Bulletin, 22(1925), 111.

21. Skinner, B. F. (1958). “Teaching machines.” Science 128 (3330): 969-77.

22. Schmelzer, R. AI Applications In Education. Retrieved from https://www.forbes.com/sites/cognitiveworld/2019/07/12/ai-applications-in-education/

23.Thorndike, E. L. (1898). Animal intelligence: Anex perimental study of the associative processes in animals. The Psychological Review: Monograph Supplements, 2(4), i109. https://doi.org/10.1037/h0092987

24. Vaquero, Luis, Rodero-Merino, Luis, Caceres, Juan \& Lindner, Maik. (2009). A Break in the Clouds: Towards a Cloud Definition. Computer Communication Review, 39, 50-55. DOI:10.1145/1496091.1496100

25. Wenger, E. (1987). Artificial Intelligence and Tutoring Systems. Los Altos, CA: Morgan Kaufmann Publisher.

\section{РЕЗЮМЕ}

Виктория Крикун, кандидат педагогических наук, Национальный университет оборони Украины имени Ивана Черняховского, г. Киев

\section{Ретроспективный анализ развития интеллектуальных адаптивных систем обучения}

В статье проанализированы особенности развития интеллектуальных адаптивных систем в научных трудах украинских и зарубежных исследователей в ретроспективном 
аспекте. Автор исследовала предпосылки создания таких систем и их структурные компоненты с иелью создания интеллектуальной адаптивной системы иноязычной подготовки офицеров ВС Украины в условиях неформального образования. Определено, что сегодня ученые сосредоточивают свои усилия на повышении адаптивности исследуемых систем благодаря использованию комплексных моделей студента и обучение с элементами искусственного интеллекта путем создания адаптивных облако ориентированных систем учебного назначения. Обосновано, что интеллектуальные адаптивные системы имеют разные возможности и особенности в контексте адаптации к изменениям студента, предоставление обратной связи преподавателю и студенту и интеллектуальной поддержки, основываясь на потребностях субъекта обучения.

Ключевые слова: программированное обучение, адаптивный алгоритм, искусственный интеллект, компьютерное адаптивное тестирование, цифровая трансформачия, непрерывное образование.

\section{SUMMARY}

Viktoriia Krykun, Candidate of Pedagogical Sciences, National Defence University of Ukraine named after Ivan Cherniakhovskyi

\section{Retrospective Analysis of Intelligent Adaptive Systems Development}

Introduction. The article deals with the analysis of the specifics of the intelligent adaptive systems development in the scientific works of the Ukrainian and foreign scientists.The author investigated the preconditions for the emergence of such systems and their components in order to create the intelligent adaptive system of foreign language training of officers of the Armed Forces of Ukraine in the context of non-formal education.

The purpose is to analyze the development of intelligent adaptive systems in the scientific works of the Ukrainian and foreign researchers in retrospect.

Methods.At different stages of scientific research, the following research theoretical methods were used: analysis and comparison of sources on the problem under study, study of workexperience in using intelligent and adaptive systems in education; and empirical (study of issues of digital technologies implementation in the World).

Results.It is substantiated that intelligent adaptive systems have different capabilities and features in the context of adaptation to student changes, providing feedback to the teacher and student and intellectual support based on the needs of the subject of educational process.

Originality.In the context of strong social and economic and technological changes, digitalization of the educational process has a special meaning. The current situation in Ukrainelaunched the digital transformation into the educational process. A wide range of functions of modern instructors and teachers could be automated in case the active implementation of intelligent adaptive systems into practice. Another tendency of the modern World is active implementation of the person-oriented approach concerning the content delivery and organization of activities in the course of studying at educational institutions.

Conclusion.The theoretical analysis of the issue under consideration has shown that the main mission of the intelligent adaptive systems in education sphere is the personification of the studying process, as well as release of teachers from administrative routine in order to improve the soft skills of the students.

Key words: programmed learning, adaptive algorithm, artificial intelligence, computer adaptive testing, digital transformation, lifelong education. 